\title{
The Changes in Experienced Teachers' Understanding towards Classroom Management ${ }^{i}$
}

\author{
Alpay Ersozlu, ${ }^{1, *}$, Dilara Cayci \\ ${ }^{1}$ Gazi Faculty of Education, Gazi University, Central Campus, Turkey \\ ${ }^{2}$ Faculty of Education, Gaziosmanpasa University, Tasliciftlik Campus, Turkey
}

Copyright $(\subset 2016$ by authors, all rights reserved. Authors agree that this article remains permanently open access under the terms of the Creative Commons Attribution License 4.0 International License

\begin{abstract}
The aim of this study is to examine the views of experienced teachers related to the changes in their understanding of classroom management in general terms until today. In this study according to the information given by teachers, it is expected to contribute to the discussions about the development of classroom management, which is a key to student success. 23 teachers who have experience of 25 or more years in teaching profession voluntarily participated in this study in which qualitative research method was adopted. Data were collected through semi-structured interview form. Interview records were documented in data analysis. The obtained documents were analyzed and evaluated with content analysis method. According to the findings of the study, with teachers' acting as guides due to the changes in the student behavior and education program, it is revealed that the teacher's dominance decreases in the classroom and teachers have more difficulty in maintaining discipline in the classroom. In line with the research results, it is suggested that pre-service teachers needs to have teaching practice course which is taught by experienced and successful mentors for a long time to become teachers with better classroom management skills.
\end{abstract}

Keywords Classroom Management, Experienced Teachers, Teacher Views

\section{Introduction}

Teaching is a profession which has unity with experience based on practice and living besides theoretical knowledge and whose artistic, social and leadership dimensions are dominant (Gökyer and Özer, 2014, p. 694) [1]. Therefore those who perform this profession lead to the individuals in all areas of education in proportion to abundance of experience alongside knowledge. Teachers' point of view on classroom management is of vital importance for the success of teaching. Teachers have been a witness to any change in the profession. Besides being a witness to the reflections of the changes on education over the years they work, they have also become both practitioners and carriers of these changes.

Classroom management is organizing and conducting necessary academic and administrative activities to create and sustain a positive learning environment and it is arranged by teachers. (Garret, 2014 [2], Brophy, 2006 [3], Erol, Özaydın and Koç 2010 [4]). The changes experienced in the teaching process can play an important role especially on classroom management. Researches on classroom management show that classroom management is a component of effective teaching and an important factor on student achievement (Marzano., Marzano and Pickering, 2003) [5]. Classroom management affects and is also affected by every phase of education. Limiting classroom management only with the classroom environment due to this property means fairly narrowing the scope of this concept. Classroom management consists of different dimensions. Ağaoğlu (2002) [6] discusses that classroom management is teacher's individual characteristics, the teaching strategies, methods and techniques which s/he uses while lecturing, his/her harmony with the social environment, the cooperation between school and family, physical conditions of the classroom, students' characteristics and requirements, the structure of the school, the rules adopted by the school and the atmosphere formed in the class. In this study, classroom management is examined within instructional design, teaching methods and strategies, communication skills, use of technology and assessment and evaluation dimensions.

The effectiveness of classroom management is defined as a learning environment which improves learning, motivation and joint function. (Shindler, 2010, s.16) [7]. An effective teacher is the teacher who can include all of the students into the teaching process not some of them and who can manage to transfer the act of teaching to students by using accurate and effective methods (Yildiz and Kangalgil, 2014, p. 64) [8]. Teachers' professional life generally consists of practices of instructional design, use of teaching methods and strategies, use of technology, communication skills, classroom management skills and assessment and evaluation. Teachers 
play an important role in determining the students' needs and what is best for them. (Shohani.,Azizifar and Kamalvand, 2014) [9]. While determining the methods and strategies they will use in teaching, teachers should take into consideration the interests and needs of students, the requirements of society and age as well as the characteristics of the subject. As effective and experienced teachers know, For many students, the level of participation and learning success in school depend on the contents' compliance with intent, attractiveness and meaningfulness (Marzano., Gaddy., Foseid., Foseid and Marzano, 2005, s.59) [10]. Constructivist approach based programs that have been brought into force in primary schools have led to radical changes in teaching and administrative duties of classroom teachers (Erçoşkun and Ada, 2014, p. 173) [11]. With the new education program that adopts the constructivist educational philosophy, teachers place the students into the centre of assessment and evaluation process as well as the educational processes. This situation has led teachers to use alternative assessment methods such as portfolio, project and performance homework rather than using paper-pencil exams and multiple-choice exams.

The effective use of technology in the teaching process might quickly have a positive impact on the school's learning environment by forming a more dynamic interaction between teacher and students, by increasing the cooperation and team work in problem solving activities; by stimulating the creativity of teacher and students and by helping students to monitor and control their own learning (OECD, 2005; cited by: Samancioğlu and Summak, 2014, p. 196) [12]. Classroom management supports successful learning conditions and every child's potential development as an integral part of teaching when successfully overcome (Johnson and Bany, 1970, s.39) [13]. The skills of clarity in communication, explaining the expected fully, communicating well with students and other staff, being sensitive in terms of affective and social aspects are among the skills that qualified teachers who will shape the next generation should have (Yüksel, 2001) [14]. The teachers who communicate effectively with their students understand them better, accept them and have positive feelings about them (Erkan and Avc1, 2014, p. 85) [15]. Hence in order to achieve academic success, teachers' competence in terms of classroom management might also need to be updated in line with the developments.

When compared with others factors including cognitive processes, home environment and parental support, school culture, curriculum design, and school demographics, classroom management has a great impact on students' learning. (Cummings, 2000 [16]). However, Teachers perceive classroom management as one of the most persistent and widespread problems in education (Savran Gencer and Çakıroğlu, 2007) [17]. Jones and Jones (2012), noted that beginning teachers, and even those who are more experienced, often struggle with creating and maintaining a well-managed classroom where students can learn (cited by: Garret, 2014, s.1) [2]. Experienced teachers see the establishment of the classroom management as one of the most important goals should be completed in the first week of the year (Unal and Unal, 2012) [18]. However, beginning teachers consider classroom management as one of the basic problems and feel that they are not prepared enough in this regard (Meister and Melnick, 2003) [19]. Therefore, teacher experience plays a decisive role teachers' regulation of teaching environment in classroom.

Sadık and Akbulut (2015) [20] stated in their study that teachers regards themselves as "very good" in their classroom management skills. Furthermore, Y1lmaz (2004) [21], found significant differences in favor of experienced teachers when the classroom management skills of novice teachers and experienced teachers are compared. At this point the things that experienced teachers experienced in terms of classroom management within years affect their behavior in the classroom and their classroom management styles in a positive way. Senemoğlu (2001) [22], indicates in the study which is carried out with primary school students and teachers that students define the characteristics of "experienced and successful" teachers as follows:

"They state that a good teacher is the one who has
respect and love for them, behaves friendly, helps them
solve their problems, motivates learning, encourages,
is cheerful, warm and wisecracker, maintains
discipline in the classroom, attracts the attention and
maintains it through the lesson, has plans and is well
prepared for his/her lesson, places importance on
his/her lesson, is enthusiastic and active and keeps the
students active too, uses equipments in order to
enhance students' learning effectively, provides an
environment in which examples from life are given, is
fair, allocates time for children who learn slowly,
encourages active participation of all of the students,
does not make any discrimination among students and
does not make students experience the feeling offailure,
helps them make up their deficiencies both throughout
and outside the lesson, reinforces, teaches the ways of
learning to children, deals with the student as a whole
and makes them gain desired behaviour by
communicating with them in a positive way."

Classroom management can be a problematic area for teachers who are new in their profession. Being experienced and having professional knowledge can play an important role in order to solve this problem (Sünbül, 1996, p. 601) [23]. This study aims to determine the changes in experienced teachers' understandings towards classroom management throughout the years that they engaged in teaching.

\section{Method}

\subsection{Research Design}

The study was designed according to qualitative study 
approach. Data were collected by using interview technique with semi-structured questions. After the interviews were recorded with a recorder, all the interviews were transcribed to the letter. Identifying information indicating that it belongs to the person who interviewed is included at the top of the page to have ready documents for analysis. The themes were determined by analysing the document. The analyses were carried out according to the answers given to these themes.

\subsection{Participants}

This study was carried out with the voluntary participation of 23 teachers who have at least 25 years of teaching experience. 17 of the teachers are male and 6 of them are female. 11 of the participant teachers have 25-29 years of experience, 6 of them have 30-34 years of experience and 6 of them have 35-39 years of experience. 15 of the participants work in Tokat, 5 of them work in Çorum and 3 of them work in Malatya. Additionally 18 of them work in state schools and 5 of them work in private schools.

\subsection{Data Collection Tool}

In this study interview data were collected by using a semi-structured interview form consisting of 5 questions. Two field experts were asked for their ideas to ensure the validity of this form and a Turkish language expert was consulted about the language and comprehensibility of this data collection tool. The interviews with the participants were carried out by getting appointments and at the time and date and in the environment they wanted. Each interview took approximately 15-20 minutes. The interviews were recorded with a recorder. The interviews were then converted into typed text on computer.

\subsection{Data Analysis}

After the data obtained from the participants were converted into the written form on computer, they were put to content analysis by the researchers. Data were encoded, themes were found, codes and themes were organized and findings were defined and interpreted (Yıldırım and Şimşek, 2005) [24]. Reliability level was determined with the formula of 'Reliability level= Agree/agree+disagree' (Miles and Hubermas, 1994) [25]. According to this, reliability level was found as .80 .

\section{Findings}

\subsection{The Effect of Course Design on Their Understanding of Classroom Management}

The process of preparing course design: Experienced teachers stated that they made the course design themselves in the first years of their profession and they expressed that this case made them more successful and dominant in the classroom.

"I believe that a teacher cannot achieve the success they wanted for unless they have made the preliminary preparation before they to the work." (T5)

They stated that today they get used to laziness by taking the advantage of the Internet and other resources. They even reported that their using the prepared plans blunts teacher's creativity during the lesson.

"In later years particularly with the emergence of guide books, we become free-riders. A little with the complacency caused by laziness and dilatoriness, we postponed the adaptation according to the conditions in the guide books as a second plan." (T1)

Time spent for preparing lesson plan: Teachers stated that they used to allocate too much time for yearly, monthly plans, plans divided into units and lesson plans and this adversely affected their care for the students. But now they stated that thanks to the guidebooks and prepared lesson plans, they only seek for the suitable plan for their classroom.

"We used to spend so much time for the plan. I mean we could barely observe status of students." (T2)

"I think that since all guide books are distributed all over the country, both a standard has been set on this issue and it has also become easier." (T4)

Finding and preparing the suitable material: Experienced teachers expressed that they used to have some difficulty in finding material and activities in the first years of their profession and they have had the opportunity to access more sources on this issue in the following years.

"When I had graduated, I had some difficulty in finding material for the course preparation. Now there are more facilities. I can easily reach especially visual aids." (T13)

\subsection{The Effect of Teaching Method and Strategies on Their Understanding of Classroom Management}

Method knowledge and ability to use: Experienced teachers stated their ideas on the changes in methods they use. They expressed that with the changes in the educational philosophy over the years, there said to be a transformation from teacher-centred teaching towards an education system in which students have a more active role. Experienced teachers gave some information about their ability and frequency to use method in the teaching process. They expressed that teachers' ability to use method is developing each year. They said that they pay attention to using more than one method in class.

"Formerly, the method and technique we call lecturing method was used mostly in classes. It was thought that it was more than helpful. But now living-learning, drama, role-play." (T2) 
"Teacher has to know all kinds of methods and techniques. You cannot apply only one method in a lesson. You apply more than one method. You do this work by associating it also with other courses." (T8)

Appropriateness to the student: They stated that the method and techniques used should be selected by considering the features of the students. They said that they prefer the methods that will appeal to different characteristics of the student.

"Our current students are active so we do more lively activities by taking their movements into consideration. We ensure their participation in the course." (T7)

"Many are stuck in the declaration method. The number of the teachers who develop strategies according to the class and students are really few." (T12)

\subsection{The Effect of Technology on Their Understanding of Classroom Management}

The knowledge and ability to use technology: Despite the fact that experienced teachers feel themselves inadequate about their technology knowledge, they stated that they use technology during teaching. They expressed that they overcome the difficulties they experience about technology by consulting younger teachers and students. In addition to this, some teachers added that consulting other too often harms their prestige in the eyes of students.

"Now I can say that most of the teachers can use the technology in the educational sense and some of our teachers have even developed software." (T3)

"Some teachers get adapted to technology by force and some teachers get adapted since they have to in one way or another... When you are behind your students, you are also behind in their eyes. A teacher must always be at least as much as the student. Student's helping the teacher may initially look very cute, however actually it is not. If you listen to the chats between students when you are involved or when a teacher leaves the classroom, you can confirm that they are very cruel." (T10)

The use of technology in in-class activities: Teachers said that they use the technology particularly on the basis of hardware and they stated that they attract students' attention for a longer time.

"Especially the projection event has also become very nice. You can even reflect books... My voice recorder event is also very effective. Children can feel like an artist." (T2)

"I love it I mean working with the computer, Ipad, preparing presentations or showing those slides to children, downloading them." (T8)

"Technology can be used in a way that attracts student's attention. Rather than lecturing ten times in history or geography, it is more effective to show once. While showing the details should not be skipped, they should be told with its reasons and its philosophy." (T11)

The widespread use of technology: Teacher thought that with the increase in the number of technological equipments, students will have some problems at some point. They stated that children who deal with technological devices for a long time have problems in socialising and have difficulty in making friends.

“Especially children's living in technology's pocket, their mingling with devices such as mobile phone can cause problems in their socialising." (T3)

"However I think that technology causes some problems ensuring permanent learning of children... It is a challenge in providing permanent learning in children. Children learn everything very quickly but cannot save into their memory." (T7)

\subsection{The Effect of Communication Skills on Their Understanding of Classroom Management}

Communication with the environment: Teachers' communication skills with families, students and colleagues are examined under this theme. They stated that experienced teachers have better relationships with parents in the first years of their profession, the parents used to be more willing to apply the warnings and suggestions made, the only thing that current parents care is the student's becoming successful in the exams. They also expressed that it is easier to reach parents via communication tools.

"When we talk about communication skill, we used to contact better with the student. Now the distance between the teacher and student is a little bit closed... In the past parents used to rely more on teachers. But now parents' confidence in the teacher is less... Their communication with the student seems to be better but I think that some of them cannot establish the distance." (T19)

They stated that students ask questions without fear in their communication with their teacher, and this strengthen the communication but the distance between student and teacher should set well.

"New generation teacher manage to communicate better." (T9)

"When we talk about communication skill, we used to contact better with the student. Now the distance between the teacher and student is a little bit closed... In the past parents used to rely more on teachers. But now parents' confidence in the teacher is less... Their communication with the student seems to be better but I think that some of them cannot establish the distance." (T19) 
They added that young teachers behave in a more embarrassed manner in the first years of their profession and they should overcome this within years. Experienced teachers emphasized that teachers who do not live in the school district are unable to understand the culture, environment and family that the students are in and they cannot properly communicate with their students.

"Although they are supposed to have the idea that I have started this career and my first duty is must be to have good communication, I saw shyness, uneasiness in them... In the following years they are expected to overcome this but on the contrary we see that they quite go into that shell... Teachers should be in most environments. They should not escape from social environments." (T5)

"You know former teachers, especially the ones who worked in the villages, used to be intertwined with people, public... Today, unfortunately there is transportation system in many places. Teachers do not often stay in the village. When they do not stay, the communication with public has been lost, of course." (T18)

The effect of 2004-2005 Program: They stated that there has been a conversion in the student-teacher communication after the 2005 program, which places the student in the centre. By means of this conversion students have started to talk more and express themselves more.

"The communication in the past was again a one-way thing. Particularly the communication inside the classroom used to contain the information provided by the teacher... Now we can talk about a multi-faceted communication. Teachers are not only the message givers but they are also in message receiver position. Now our students have come to a position where they question the reason why." (T3)

The effect student success: They emphasized that as teachers' communication with the environment gets stronger, this becomes effective on student success. They said that when the teacher's communication is weak, it will weaken the classroom management and this is a direct obstacle for the student success.

"Likewise, when teacher-student communication is not a very good level, you cannot manage the classroom. If a student knows that teacher loves him/her and does useful things for him/her, I mean if the student understands the teacher and the teacher understands the students, you have success." (T16)

"I can easily say that a teacher can achieve success as much as the communication s/he establishes with the school administration, environment, parents and students." (T3)

\subsection{The Effect of Assessment and Evaluation Approaches on Their Understanding of Classroom Management}

The Subjectivity-objectivity of assessment and evaluation: Experienced teachers expressed that they used to assess their teaching themselves since they used to prepare the questions themselves in the first years of their profession and this decreased the objectivity of assessment and evaluation at the same time. Moreover they stated that the fact that central exams affect the average of the school has increased that pressure on teachers and this does undermine the objectivity of their exam results.

"When there is a draw in common exams (TEOG), the school performance will be viewed. Thus a voice inevitable says let your student become successful... Do not let the child be aggrieved or let the students in your school to be in a higher group. And unfortunately I'm talking about myself we do not either behave fairly or suitably." (T6)

"Now I mean they constantly want us to decide in favour of the student. Even if the student fails, or does not listen in the classroom and thus does not have good grades, they say that give them higher grades." (T20)

The changes in the understanding of assessment and evaluation: Experienced teacher indicated that the written exams that they do evaluate the students just that instant, with the changing program they evaluate the semester of the students. They argued that the conversion of assessment and evaluation into multiple-choice exams has had a negative impact on students' higher-order thinking skills.

"In the past, evaluations were often made with open-ended questions. Test technique was not used so much. This naturally used to affect student's ability to comment, analyse and syntheses in a positive way. However through the process, evaluation have become with mainly tests. This naturally affects children's skills of producing, thinking in a negative way." (T3)

Furthermore they stated that the absence of class repetition disrupts education. They emphasized that the fact that there is no exam in elementary school is also a situation that affects students and education adversely.

"Even if it is legally forbidden to give written exams until $3^{\text {rd }}$ grade in primary school, today when we go to the stationer's, we see that the tests, exams start from the $1^{\text {st }}$ grade." (T4)

"Already there is not such a thing as failing the class in the first 4 classes. We are forced to let the student pass. This causes the disruption of education." (T16)

\section{Discussion, Results and Suggestions}

The findings of this study indicate that due to the changes 
on behaviors of students from past to present and changes in teacher roles, the dominance of teachers in classes has decreased and therefore maintaining discipline in classes has been more difficult for teachers. Experienced teachers stated that there has been a standard in terms of course design all over the country with the emergence of guidebooks but this situation has led teachers to become free riders. Dinç and Doğan (2010) [26] indicated in their study that teacher guidebooks guide teachers despite their lacks.

Teachers expressed that they have observed positive developments in terms of the method and strategies both in quantitative and qualitative aspects. With the 2004-2005 education program which has adopted constructivist approach teachers have attempted to use methods and strategies that will attract students' attention and will make their learning meaningful during teaching.

Teachers stated that the inclusion of technology into education helps students to give their attention to the course but at the same time it affects adversely the cognitive and social skills of children who play with technological devices too much. Likewise Çağıltay, Çakıroğlu, Çă̆lltay and Çakıroğlu (2001) [27] found that the use of technology in teaching is welcomed by teachers but teachers have important lacks in technology proficiency.

Even if it is said that the communication with environment is better than it was in the past, they said that some problems experienced negatively affects teaching. Çetinkaya (2011) [28] stated in his study that teachers' communication skills are a crucial characteristic in terms of the effectiveness of education and student success.

Teachers indicated that the fact that the assessment and evaluation is multi-faceted and is carried out based on process gives more information about student's development. Likewise Anıl and Acar (2008) [29]) stated in the study which they carried out with classroom teachers that the results obtained from traditional assessment methods do not offer detailed information about students and teachers have lacks of knowledge and practice in terms of alternative assessment methods.

When all results are considered, although experienced teachers try to adapt to the changes, they try to protect the classroom management approach they have acquired in beginning of their profession. Experienced teachers try to blend their traditional approaches in classroom management with constructivist approach.

It is suggested that teachers should follow academic and scientific studies in order to develop themselves. It is also recommended that various team works and workshops in which experienced and novice teachers are able to help each other should be held.

\section{REFERENCES}

[1] Gökyer, N., Özer, F. (2014). Aday öğretmenlerin sınıf yönetimi yeterliliklerine ilişkin algıları. Electronic Turkish Studies, 9(2), 691-712.

[2] Garret, T. (2014). Effective classroom management the essentials. New York: College Press.

[3] Brophy, J. (2006). History of research. In C. M. Evertson \& C. S. Weinstein (Eds.), Handbook of classroom management: Research, practice, and contemporary issues (pp. 17-43). Mahwah, NJ: Lawrence Erlbaum Associates.

[4] Erol, O., Özaydın, B., Koç, M. (2010). Sınıf yönetiminde karşılaşılan olaylar, öğretmen tepkileri ve öğrenciler üzerindeki etkileri: unutulmayan sınıf anılarının analizi. Kuram ve Uygulamada Eğitim Yönetimi, 16(1), 25-47.

[5] Marzano, R. J., Marzano, J. S., Pickering, D. J. (2003). Classroom management that works: Research based strategies for every teacher. Alexandria, VA: Association for Supervision and Curriculum Development.

[6] Ağaoğlu, E. (2002). Sınıf yönetimi ile ilgili genel olgular. Z. Kaya (Ed.). Sınıf Yönetimi içinde. Ankara: Pegem-A Yayınları..

[7] Shindler, J. (2009). Transformative classroom management: Positive strategies to engage all students and promote a psychology of success. San Francisco: John Wiley \& Sons.

[8] Yıldiz, E., Kangalgil, M. (2014). Beden eğitimi öğretmenlerinin mesleki yeterlikleri ve kullandıkları öğretim yöntemleri ile ilgili görüşlerinin incelenmesi. Pamukkale Journal of Sport Sciences, 5(1), 61-76.

[9] Shohani, S., Azizifar, A., Kamalvand, A. (2014). The Relationship between Novice and Experienced Teachers' Self-Efficacy for Classroom Management and Students' Perceptions of their Teachers' Classroom Management. Research on Humanities and Social Sciences, 4(16), 134-148.

[10] Marzano, R. J., Gaddy, B. B., Foseid, M. C. (2005). A handbook for classroom management that works. Alexandria, VA: ASCD.

[11] Ercoşkun, M. H., Ada, Ş. (2014).Etkili sınıf yönetimi oluşturmada sınıf öğretmenlerinin yeni rollerinin nicel açıdan incelenmesi. Atatürk Üniversitesi Sosyal Bilimler Enstitüsü Dergisi, 18(2), 171-194.

[12] Samancioğlu, M., Summak, M. S. (2014). Öğretmenlerin derslerde teknoloji kullanımlarını etkileyen faktörler: kişisel bilgisayar kullanımı ve öğretim yaklaşımları. Atatürk Üniversitesi Sosyal Bilimler Enstitüsü Dergisi, 18(2), 195-207.

[13] Johnson, L. V., Bany, M. A. (1970).Classroom Management: Theory \& skill training. New York: Macmillan.

[14] Yüksel, G. (2001). Öğretmenlerin sahip olmaları gereken davranış olarak sosyal beceri. Milli Eğitim Dergisi, 150

[15] Erkan, Z., Avcı, R.(2014). Öğretmen adaylarının iletişim becerileri: mizaç ve karakter özelliklerinin rolü. Mersin Üniversitesi Eğitim Fakültesi Dergisi, 10(1), 84-94.

[16] Cummings, C. B. (2000). Winning strategies for classroom management. Alexandria, VA: ASCD.

[17] Savran Gencer, A., Cakıroğlu, J. (2007). Turkish preservice science teachers' efficacy beliefs regarding science teaching and their beliefs about classroom management. Teaching and Teacher Education, 23(5), 664-675. 
[18] Ünal, Z., Ünal, A. (2012). The impact of years of teaching experience on the classroom management approaches of elementary school teachers. International journal of Instruction, 5(2).

[19] Meister, D. G., Melnick, S. A. (2003). National new teacher study: Beginning teachers' concerns. Action in Teacher Education, 24(4), 87-94.

[20] Sadık, F., Akbulut, T. (2015). An Evaluation of Classroom Management Skills of Teachers at High Schools (Sample from the City of Adana). Procedia-Social and Behavioral Sciences, 191, 208-213.

[21] Y1lmaz, E. (2004). The relationship between novice and experienced teachers' self-efficacy for classroom management and students' perceptions of their teachers' classroom management. Unpublished master's thesis, Bilkent University, Ankara.

[22] Senemoğlu, N. (2001). Öğrenci görüşlerine göre öğretmen yeterlikleri. Eğitimde Yansımalar: Altıncı 2000'li Yıllarda Türk Milli Eğitim Örgütü ve Yönetimi. 11-13 Ocak 2001. Ankara: Öğretmen H. Hüseyin Tekışık Eğitim Araştırma ve Geliştirme Vakfi.

[23] Sünbül, A. M. (1996). Öğretmen niteliği ve öğretimdeki rolleri. Kuram ve Uygulamada Eğitim Yönetimi, 2(4), 597-608.

[24] Yıldırım, A., Şimşek, H. (2005). Sosyal bilimlerde nitel araştırma yöntemleri. Ankara: Seçkin Yayıncılık.

[25] Miles, M. B., Huberman, A. M. (1994). Qualitative data analysis. California: SAGE Publications Inc..

[26] Dinç, E., Doğan, Y. (2010). İlköğretim ikinci kademe sosyal bilgiler öğretim program ve uygulanması hakkında öğretmen görüşleri. Sosyal Bilgiler Eğitimi Araştırmaları Dergisi, 1(1), 17-49.

[27] Cağgltay, K., Cakıroğlu, J., Cağğltay, N., Cakıroğlu, E. (2001). Öğretimde bilgisayar kullanımına ilişkin öğretmen görüşleri. Hacettepe Üniversitesi Eğitim Fakültesi Dergisi, 21(21), 19-28.

[28] Çetinkaya, Z. (2011).Türkçe öğretmen adaylarının iletişim becerilerine ilişkin görüşlerinin belirlenmesi. Kastamonu Ĕ̆itim Dergisi, 19(2), 567-576

[29] Anıl, D., Acar, M. (2008). Sinıf öğretmenlerinin ölçme değerlendirme sürecinde karşılaştıkları sorunlara ilişkin görüşleri. Yüzüncü Yıl Üniversitesi Eğitim Fakültesi Dergisi, 5(2), 44-61.

\footnotetext{
i This paper was revised after being presented at ERPA International Congresses on Education, Athena, Greece, 4-7 June 2015.
} 